\title{
EFFECTS OF HIS-PHE-ARG-TRP-PRO-GLY-PRO PEPTIDE ON FREE-RADICAL OXIDATION PROCESSES IN CONDITIONS OF CHRONIC RESTRAINT STRESS
}

Vorvul $\mathrm{AO}^{1} \otimes$, Bobyntsev $\mathrm{II}^{1}$, Medvedeva $\mathrm{OA}^{1}$, Azarova YuE${ }^{1}$, Belykh AE${ }^{1}$, Andreeva LA²

${ }^{1}$ Kursk State Medical University, Kursk, Russia

2 Institute of Molecular Genetics, RAS, Moscow, Russia

\begin{abstract}
Studying the effects of regulatory peptides on the stress-induced shifts in the bodily processes is of great fundamental and applied significance. Currently, a wide range of peptide neurotropic drugs, affecting the stress response development, are used in medicine, and new promising molecules are being studied. The study was aimed to assess the effects of the adrenocorticotropic hormone (ACTH) synthetic analog, ACTH(6-9)-Pro-Gly-Pro, administered at a dose of 5, 50 and 500 $\mu g / \mathrm{kg}$, on the free-radical oxidation processes in Wistar rats, subjected to chronic restraint stress (CRS) during two weeks. Serum levels of 8-oxo-2'-deoxyguanosine (8-OHdG) and superoxide dismutase 3 (SOD3) were assessed by enzyme immunoassay, and the levels of thiobarbituric acid reactive substances (TBARS) were assessed by fluorimetric method. CRS lead to the significant increase in the $8-O H d G$ levels by $18.4 \%(p=0.01)$ and the decrease in the SOD3 levels by $14.3 \%$ $(p=0.01)$, however, it had no effect on the levels of TBARS. ACTH(6-9)-Pro-Gly-Pro, administered at a dose of 5 and $50 \mu \mathrm{g} / \mathrm{kg}$, significantly decreased the levels of $8-\mathrm{OHdG}$ by $19.8 \%(p=0.03)$ and $30 \%(p=0.001)$, respectively. Thus, it was found that CRS resulted in oxidative stress in animals. ACTH(6-9)-Pro-Gly-Pro administration at a dose of 5 and $50 \mu \mathrm{g} / \mathrm{kg}$ inhibits the stress-induced free-radical oxidation processes.
\end{abstract}

Keywords: regulatory peptides, His-Phe-Arg-Trp-Pro-Gly-Pro, ACTH(6-9)-Pro-Gly-Pro, free-radical oxidation, oxidative stress, chronic restraint stress

Author contribution: Vorvul AO - performing experiments, quantification of oxidative stress markers, data acquisition and statistical processing, manuscript writing; Bobyntsev II — study concept and design, manuscript writing; Medvedeva OA — study concept and design; Azarova YuE — quantification of oxidative stress markers; Belykh AE — manuscript writing; Andreeva LA — study concept and design, peptide synthesis.

Compliance with ethical standards: the study was approved by the Ethics Committee of the Kursk State Medical University (protocol № 3 dated November 16, 2020). All the experiments were in line with the ARRIVE guidelines and were performed in accordance with the Directive 2010/63/EU of the European Parliament and of the Council on the protection of animals used for scientific purposes.

$\triangle$ Correspondence should be addressed: Anton O. Vorvul

Karla Marxa, 3, Kursk, 305041, Russia; vorvul1996@mail.ru

Received: 28.10.2021 Accepted: 14.11.2021 Published online: 28.11.2021

DOI: $10.24075 /$ brsmu.2021.056

\section{ВЛИЯНИЕ ПЕПТИДА НIS-PHE-ARG-TRP-PRO-GLY-PRO НА ПРОЦЕССЫ СВОБОДНОРАДИКАЛЬНОГО ОКИСЛЕНИЯ В УСЛОВИЯХ ХРОНИЧЕСКОГО ИММОБИЛИЗАЦИОННОГО СТРЕССА}

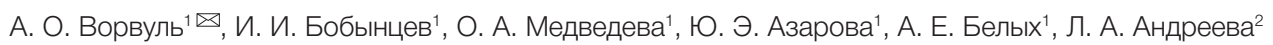 \\ ${ }^{1}$ Курский государственный медицинский университет, Курск, Россия \\ 2 Институт молекулярной генетики РАН, Москва, Россия
}

\begin{abstract}
Изучение влияния регуляторных пептидов на развитие стресс-индуцированных сдвигов в организме имеет важное фундаментальное и прикладное значение. В настоящее время в медицине используют целый ряд нейротропных препаратов пептидной природы, оказывающих влияние на развитие стрессорной реакции, а также ведут исследование новых перспективных молекул. Целью работы было изучить эффекты синтетического аналога адренокортикотропного гормона (АКТГ) АКТГ(6-9)-Pro-Gly-Pro в дозах 5, 50 и 500 мкг/кг на процессы свободнорадикального окисления у крыс Вистар в условиях двухнедельного хронического иммобилизационного стресса (ХИС). Уровни 8-оксо-2'-дезоксигуанозина (8-ОНdG) и супероксиддисмутазы 3 (СОДЗ) в сыворотке крови оценивали с применением иммуноферментного анализа, а уровни продуктов, реагирующих с тиобарбитуровой кислотой (ТБК-РП), оценивали флуориметрическим методом. ХИС приводил к значимому повышению уровня 8-OHdG на 18,4\% (p = 0,01) и снижению СОД3 на 14,3\% ( $p=0,01)$, но не влиял на уровень ТБК-РП. Применение АКТГ(6-9)-Pro-Gly-Pro в дозах 5 и 50 мкг/кг значимо снижало содержание 8-ОНdG на 19,8\% ( $p=0,03)$ и 30\% ( $p=0,001)$ соответственно. Таким образом, установлено, что ХИС приводит к развитию окислительного стресса у животных. Введение АКТГ(6-9)-Pro-Gly-Pro в дозах 5 и 50 мкг/кг оказывает ингибирующее влияние на стресс-индуцированные процессы свободнорадикального окисления. Ключевые слова: регуляторные пептиды, His-Phe-Arg-Trp-Pro-Gly-Pro, АКТГ(6-9)-Pro-Gly-Pro, свободнорадикальное окисление, окислительный стресс, хронический иммобилизационный стресс

Вклад авторов: А. О. Ворвуль - выполнение экспериментов, количественная оценка маркеров окислительного стресса, сбор и статистическая обработка данных, написание рукописи; И. И. Бобынцев - концепция и дизайн исследования, написание рукописи; О. А. Медведева - концепция и дизайн исследования; Ю. Э. Азарова — количественная оценка маркеров окислительного стресса; А. Е. Белых — написание рукописи; Л. А. Андреева — концепция и дизайн исследования, синтез пептида.

Соблюдение этических стандартов: исследование одобрено этическим комитетом Курского государственного медицинского университета (протокол № 3 от 16 ноября 2020 г.). Все эксперименты соответствовали руководящим принципам ARRIVE и были проведены в соответствии с директивой
\end{abstract} 2010/63/EU Европейского парламента и Совета Европейского союза по охране животных, используемых в научных целях.

$\triangle$ Для корреспонденции: Антон Олегович Ворвуль ул. К. Маркса, д. 3 г. Курск, 305041, Россия; vorvul1996@mail.ru

Статья получена: 28.10.2021 Статья принята к печати: 14.11.2021 Опубликована онлайн: 28.11.2021

DOI: $10.24075 /$ vrgmu.2021.056

Activation of free-radical oxidation is one of the main mechanisms, underlying cell damage, resulting from the organism's exposure to stressor [1, 2], which determines the relevance of searching for effective approaches to cytoprotection under the condition of stress.
The use of peptide molecules could be one of the promising directions for solving the mentioned above problems [3, 4]. No toxicity and allergenic capacity along with the broad spectrum of physiological and pharmacological activity is the advantage of using the drug products based on regulatory peptides [5]. 
These molecules include regulatory peptides, belonging to the group of $\mathrm{N}$-terminal analogs of adrenocorticotropic hormone (ACTH). It is well known that Semax, containing the ACTH(4-7)Pro-Gly-Pro synthetic peptide as an active substance, corrects histoarchitectonics and free-radical oxidation processes in the liver, as well as serum transaminases levels in the stressed rats [6]. Furthermore, Semax exhibits neuroprotective effects due to increased expression of brain-derived neurotrophic factor (BDNF) in the conditions of brain ischemia [7].

The His-Phe-Arg-Trp-Pro-Gly-Pro peptide (ACTH(6-9)Pro-Gly-Pro) is structurally and functionally related to Semax. The His-Phe-Arg-Trp sequence, matching the ACTH(6-9) region, is an active center of $\mathrm{ACTH}$, which interacts with melanocortin receptors (MCR) of all types, except MC2R [8]. However, attachment of the Pro-Gly-Pro tripeptide to the $\mathrm{C}$-terminus of this molecule increases the molecule resistance to carboxypeptidases against the background of preserved neurotropic effects. Like Semax, ACTH(6-9)-Pro-Gly-Pro exhibits a broad range of neurotropic effects, including in the stressor load models, and is capable of exhibiting the more prominent activity when administered at comparable doses [9].

Therefore, the study was aimed to assess the effects of the ACTH(6-9)-Pro-Gly-Pro peptide on the free-radical oxidation processes in rats subjected to chronic restraint stress (CRS).

\section{METHODS}

\section{Animals}

The experiment involved 55 male Wistar rats weighting 280-300 g. The temperature of $22 \pm 2{ }^{\circ} \mathrm{C}$, humidity of $60 \pm 5 \%$, and the 12-hour light/dark cycle (light on from 8:00 to 20:00) were maintained in the room where the animals were kept. The animals were provided ad libitum access to food and water. The rats were divided into five groups, 11 rats per group: 1 - intact animals (administration of normal saline (NS) with no stress applied), 2 - control group (CRS + NS), 3 - CRS + ACTH(6-9)-

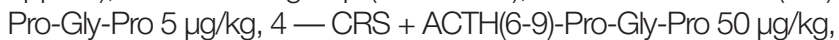
$5-\mathrm{CRS}+\mathrm{ACTH}(6-9)$-Pro-Gly-Pro $500 \mu \mathrm{g} / \mathrm{kg}$.

\section{Chronic restraint stress}

The CRS model was modeled by placing the rats in the tight transparent plastic boxes with ventilation holes, the size of which was adjusted individually for each animal. The animals were subjected to stress for $2 \mathrm{~h}$ (from 11:00 to 13:00) during 14 days (Fig. 1) [10].

\section{Peptide}

The N-terminal analog of ACTH, ACTH(6-9)-Pro-Gly-Pro (His-Phe-Arg-Trp-Pro-Gly-Pro), synthesized in the Institute of Molecular Genetics of the National Research Centre "Kurchatov Institute" (RAS), was used during the study, which was dissolved in NS and administered intraperitoneally at a dose of 5,50 and $500 \mu \mathrm{g} / \mathrm{kg}$ daily $12-15 \mathrm{~min}$ before stress exposure in a volume of $1 \mathrm{~mL}$ per $1 \mathrm{~kg}$ of body weight. Intact animals and controls received equivalent amounts of NS on a daily basis. The peptide doses and the procedure for administration, used during the experiment, were selected in accordance with the available literature data on their efficacy $[9,11]$.

\section{Blood serum collection}

The animals were euthanized $24 \mathrm{~h}$ after the final stress exposure by blood withdrawal from the right ventricle of the heart after performing parasternal bilateral thoracotomy under ether anesthesia using the S-Monovette vacuum system with procoagulant (SARSTEDT; Germany). A total of 7.0-7.5 mL of blood was collected; the vacuum system needle position was assessed visually. The blood samples collected were centrifuged at $1500 \mathrm{~g}$ for $15 \mathrm{~min}$. The serum obtained was distributed in $200 \mu \mathrm{L}$ aliquotes in the clean individual microtubes, frozen at $-20{ }^{\circ} \mathrm{C}$, and then stored at $-80^{\circ} \mathrm{C}$ for further study. Aliquotes were thawed at room temperature for $4 \mathrm{~h}$ prior to analysis.

\section{Assessing the intensity of free radical processes and the stress response intensity}

The nucleic acid metabolite 8-oxo-2'-deoxyguanosine (8-OHdG) was selected as a marker of oxidative damage to cellular DNA, it was assessed by enzyme immunoassay (ELISA) using the DNA/RNA Oxidative Damage (High Sensitivity) ELISA Kit (589320, Cayman Chemical; USA). Moreover, the concentration of extracellular superoxide dismutase (SOD3) was defined by ELIZA using the ELISA Kit For Superoxide Dismutase 3, Extracellular (SEA117Ra, Cloud-Clone Corp.; USA); thiobarbituric acid reactive substances (TBARS) were assessed by fluorimetric method using the TBARS (TCA Method) Assay Kit (700870, Cayman Chemical; USA).

To evaluate the stress response intensity, corticosterone serum levels were defined by enzyme immunoassay using the Corticosterone ELISA kit (ADI-900-097, Enzo Life Sciences; USA).

All the assays were performed in accordance with the manufacturers' procedures. Absorbance and fluorescence were registered and analyzed using the Varioskan Flash advanced spectral scanning multimode reader (Thermo Fisher Scientific; USA) and the Skanlt software (Thermo Fisher Scientific; USA).

\section{Statistical analysis}

Statistical processing of the data obtained was performed using v.4.1.0 of R language [12] in the RStudio Desktop V. 1.4.1717 integrated development environment (RStudio, PBC; USA; https://www.rstudio.com). The Shapiro-Wilk test was used for the normality hypothesis test, and equality of variances was tested using the Levene's test. In case of the hypothesis confirmation, two groups were compared using the Welch's t-test, and four groups were compared using oneway ANOVA with post hoc Newman-Keuls test. In case of the hypothesis rejection, the Mann-Whitney $U$ test was used for two groups, and the Kruskal-Wallis test with post hoc Dunn's test were used for four groups. The Benjamini-Hochberg procedure was applied to reduce the false discovery rate. The differences were considered significant when $p<0.05$.

\section{RESULTS}

The study found that CRS resulted in oxidative stress (Fig. 2). Thus, a significant increase in the levels of $8-\mathrm{OHdG}$ by $18.4 \%$ $(p=0.01)$ along with the significant decrease in the levels of SOD3 by $14.3 \%(p=0.01)$ against the background of CRS were observed. However, the concentration of TBARS did not change $(p=0.43)$.

At the same time, it has been shown that ACTH(6-9)-Pro-GlyPro corrects the CRS-induced oxidative stress. The significant differences in the serum 8-OHdG levels ( $p=0.0004)$ between the controls, subjected to stress, and the animals, receiving the peptide, have been revealed. However, no significant differences in the levels of SOD3 $(p=0.2)$ have been found. 


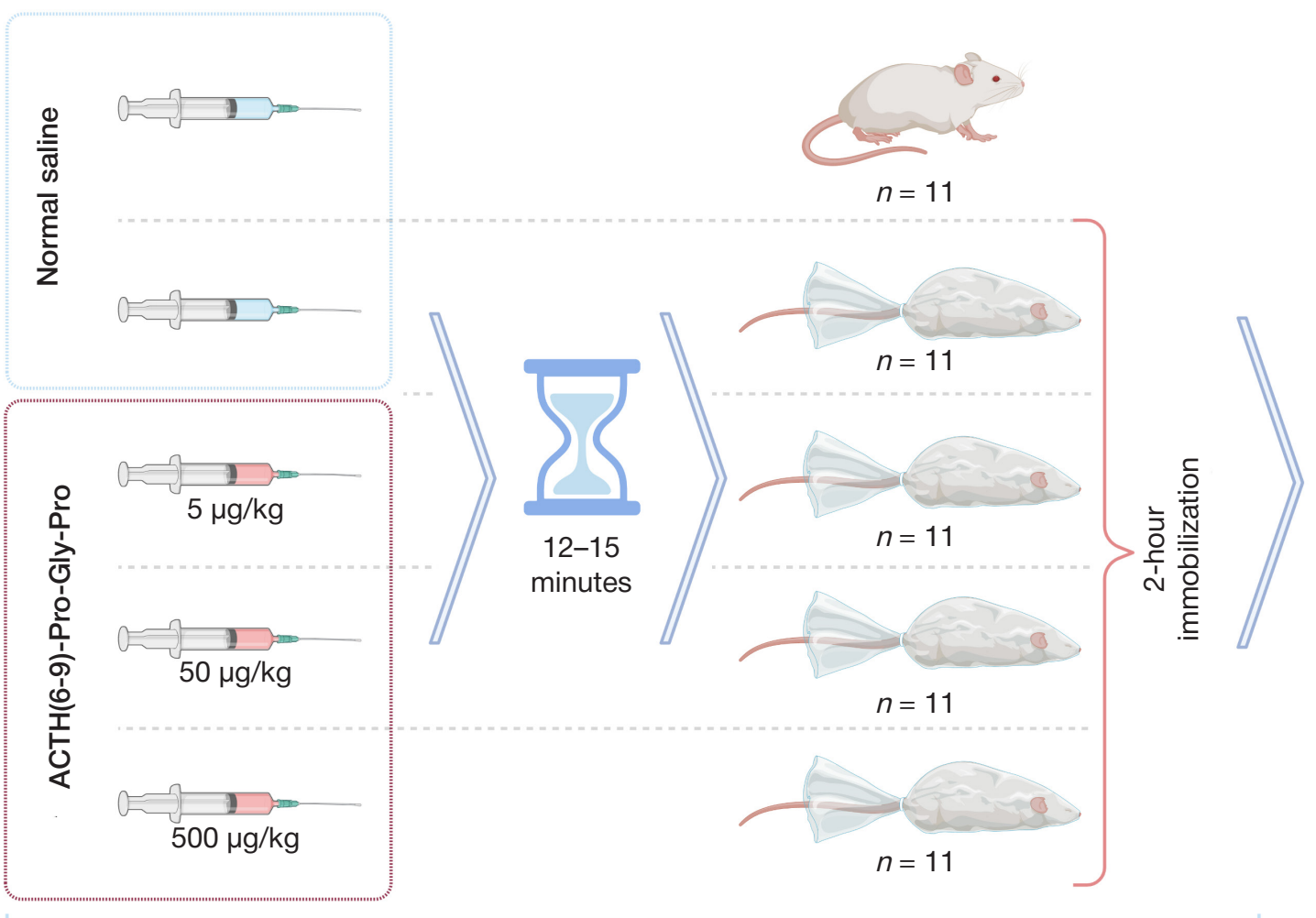

14 days
EUTHANASIA

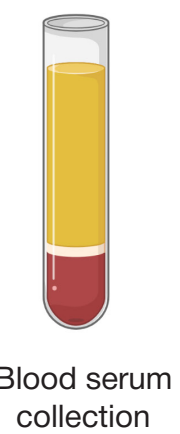

Fig. 1. Study design

The post hoc analysis has found that the serum $8-\mathrm{OHdG}$ levels significantly decreased by $19.8 \%(p=0.03)$ and $30 \%$ ( $p=0.001$ ), respectively, after the ACTH(6-9)-Pro-Gly-Pro administration at a dose of 5 and $50 \mu \mathrm{g} / \mathrm{kg}$. However, peptide administration at a maximum dose of $500 \mu \mathrm{g} / \mathrm{kg}$ had no effect on the 8-OHdG levels ( $p=0.72$ ).

Based on the data obtained, it was also found that the significant increase in the levels of corticosterone by $27 \%$ $(p=0.009)$ was observed in the CRS model. The use of ACTH(6-9)-Pro-Gly-Pro resulted in significanly altered levels of the hormone $(p=0.003)$. The post hoc analysis showed that ACTH(6-9)-Pro-Gly-Pro administration at a dose of 5, 50, $500 \mu \mathrm{g} / \mathrm{kg}$ resulted in the significant decrease in the levels of corticosterone by $34.9 \%(p=0.004), 16.4 \%(p=0.04)$, and $28.6 \%(p=0.01)$, respectively.

\section{DISCUSSION}

The effects of the ACTH(6-9)-Pro-Gly-Pro peptide on the freeradical oxidation processes in rats against the background of CRS were assessed during the study. The free-radical oxidation markers, which were used in the study, were selected based on their diagnostic and pathophysiology value. Thus, $8-\mathrm{OHdG}$ is a reliable biomarker of the generalized and cellular oxidative stress, and an important indicator of oxidative brain damage in acute ischemic stroke, atherosclerosis, cardiovascular diseases, neurodegenerative disorders, such as Alzheimer's disease and Parkinson's disease, as well as in mental disorders, such as schizophrenia, etc. [13]. The other selected marker of oxidative stress is malondialdehyde (MDA), resulting from peroxidation of polyunsaturated fatty acids, which is used as an indicator of the reactive oxygen species-mediated damage to cell membranes. The levels of MDA are measured by TBARS assessment [14]. SOD is a first-line antioxidant, which initiates activation of protection against the reactive oxygen species [15]. Three isoforms of SOD have been reported, however, extracellular SOD3 is a predominant antioxidant enzyme of blood serum, and the role of SOD3 is not confined to free-radical scavenging, but also involves the impact on the immune response and cell signaling [16]. Consequently, ELISA was used as a reliable and specific research method, allowing one to identify this exact isoform of the enzyme, in order to evaluate the SOD3 level changes in the conditions of CRS and peptide administration.

The study found that CRS resulted in significantly increased concentrations of the DNA/RNA free-radical oxidation products in blood serum of experimental animals. These results were obtained in the similar C57BL/6J murine model of chronic stress [17]. Furthermore, CRS resulted in the decreased SOD3 levels. It should be noted that free-radical oxidation activation and the decrease in the SOD3 concentration occurred against the background of the elevated corticosterone blood levels. It is known that elevated corticosterone levels are accompanied by a decline in the antioxidant enzyme system activity [18]. Thus, the chronic stress model, which was used in the study, induced activation of the free radical oxidation processes.

It was found that CRS caused no significant changes in the levels of TBARS. However, there are contradictory data in the literature regarding the serum levels of this marker under prolonged stressor exposure. Thus, in a number of studies, chronic stress resulted in significantly increased serum concentrations of TBARS $[19,20]$. However, the changes observed occurred against the background of chronic unpredictable stress, characterized by exposure to stressors of various intensity, while we used a model involving exposure to monotonous stress. At the same time, there are some papers, reporting no significant changes in the serum levels of TBARS in the experimental conditions similar to ours, regardless of the significantly increased MDA concentration in the organs and tissues $[18,21]$. It is also important to mention that, despite their speed and simplicity, fluorometric and spectrophotometric 
8-OHdG $(\mathrm{ng} / \mathrm{mL})$

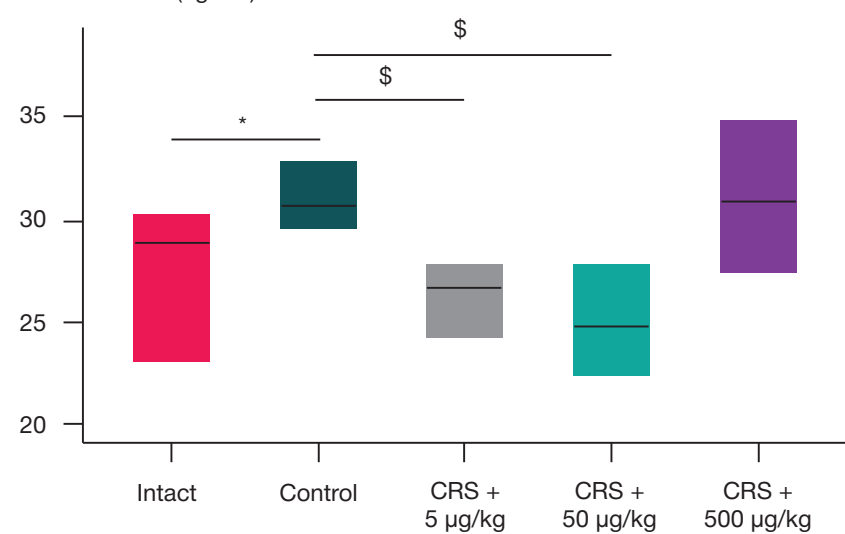

TBARS $(\mu \mathrm{mol} / \mathrm{L})$

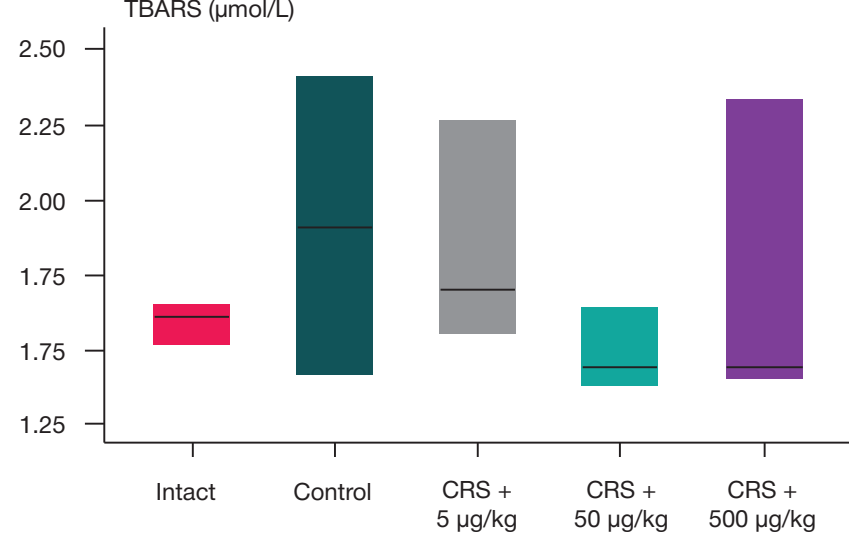

SOD3 $(\mu \mathrm{g} / \mathrm{mL})$

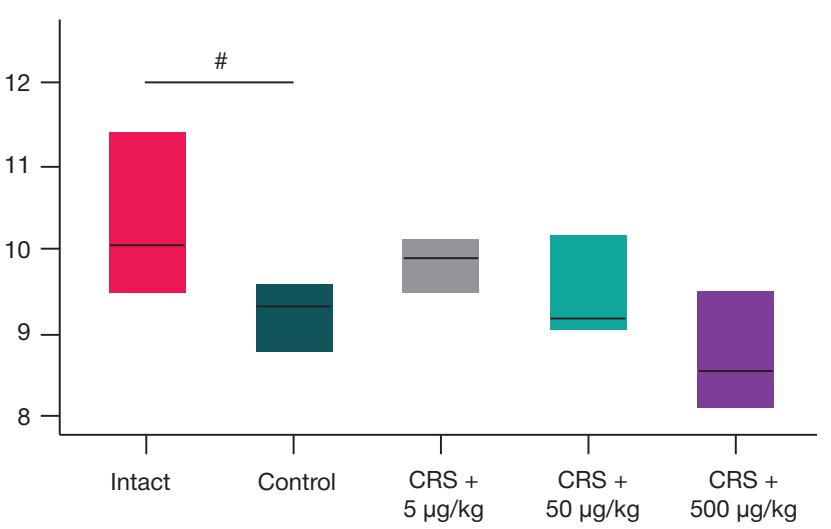

Corticosterone $(\mathrm{ng} / \mathrm{mL})$

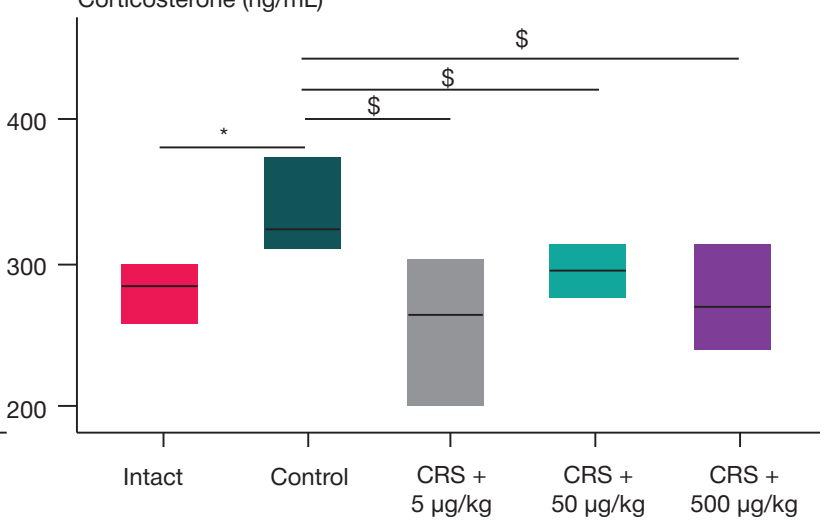

Fig. 2. Effects of the ACTH(6-9)-Pro-Gly-Pro peptide on the intensity of free-radical processes and stress response intensity against the background of CRS. $*-p<0.05$, significance level of the differences compared with the control group not subjected to stress (based on Welch's $t$-test); $\#-p<0.05$, significance level of the differences compared with the control group (based on Mann-Whitney U-test); $\$-p<0.05$, significance level of the differences compared with the control group subjected to stress (based on one-way ANOVA with post hoc Newman-Keuls test); semi-bold bar — median; box — interquartile range.

methods for TBARS assessment are not always reliable in heterogeneous systems due to the potential of aldehydes other than MDA to produce derivatives, absorbing light in the same wavelength range [14]. At the same time, the lack of significant changes in the serum concentrations of TBARS may be also due to the increase in the activity of the antioxidant mechanisms, unexplored during our study, by the end of the experiment. Therefore, clarifying the mechanisms, underlying alterations in the free-radical oxidation processes, identified during our study, requires further identification of a number of additional markers in blood serum.

ACTH(6-9)-Pro-Gly-Pro, administered at a dose of 5 and 50 $\mu \mathrm{g} / \mathrm{kg}$, reduced the intensity of free-radical oxidation processes, as reflected in the significantly decreased $8-\mathrm{OHdG}$ levels. In this regard, it should be pointed out that $\mathrm{ACTH}(4-7)$-Pro-Gly-Pro (Semax), which is similar to $\mathrm{ACTH}(6-9)-P r o-G l y-P r o$ based on its structural and functional properties, administered at comparable doses, has a cytoprotective effect on the neurons of the brain in the conditions of ischemia, in particular, due to the elevated neuronal expression of $\operatorname{BDNF}[6,22,23]$. Considering the fact that stroke involves activation of oxidative stress [24, 25], correction of free-radical oxidation processes by administration of ACTH(6-9)-Pro-Gly-Pro, found during our study, may be also of some significance for cytoprotection.

Furthermore, the mechanisms, underlying cytoprotective effects of the peptide, may be associated with modulation of NF- $\mathrm{KB}$ activity and activation of the redox-sensitive NRF2 signaling pathway, which have been defined when studying the protective effects of $\mathrm{ACTH}(6-9)$-Pro-Gly-Pro on the $\mathrm{SH}$ SY5Y cells in the conditions of hydrogen peroxide-induced cytotoxicity [26].
Moreover, it is well known that hypothalamic-pituitaryadrenal axis, involved in both production and release of cortisol, is capable of increasing oxidative stress due to modulation of the reactive oxygen species production together with mitochondrial calcium homeostasis. However, cortisol levels correlate positively with plasma 8-OHdG concentrations [27]. Given the neurotropic activity, exhibited by ACTH(6-9)-Pro-Gly-Pro [9], it can be assumed that the anti-stress effects of the substance may be also associated with modulation of stress response in the central nervous system, as evidenced by simultaneous decrease in the levels of cortisol and 8-OHdG, observed during our study.

The differences in the effects of ACTH(6-9)-Pro-Gly-Pro depending on the dose, in particular, the lack of activity when using the maximum dose $(500 \mu \mathrm{g} / \mathrm{kg})$, is typical for regulatory peptides [5, 9]. Thus, as it has been shown for melanocortins, the signal is transduced from MCR via interaction with adenylyl cyclase and activation of the CAMP signaling pathway [28]. However, the signal transduction pathways may depend on the ligand concentration and the transduction may involve other secondary messenger systems, which may affect the effects direction and severity. For example, the signal from MC3R may be transmitted via phosphoinositol pathway [29], and the signal transduction from MC5R may involve Jak/STAT [30].

\section{CONCLUSIONS}

The study showed that in animals, chronic (14-day) restraint stress resulted in activation of the free-radical oxidation processes. Administration of ACTH(6-9)-Pro-Gly-Pro at a dose of 5 и $50 \mu \mathrm{g} / \mathrm{kg}$ reduced the intensity of stress response and inhibited the stress-induced free-radical oxidation processes. 
Our findings and the data of other studies, focused on the effects of the $\mathrm{N}$-terminal $\mathrm{ACTH}$ analogs, indicate the need for further investigation of the mechanisms underlying the effects of those on the stress-induced free-radical oxidation with the use of more complex evaluation of the wider range of prooxidant and antioxidant system markers.

\section{References}

1. Sies $H$, Berndt C, Jones DP. Oxidative stress. Annu Rev Biochem. 2017; 86: 715-48. DOI: 10.1146/annurevbiochem-061516-045037. PubMed PMID: 28441057.

2. Sies H. Oxidative stress: concept and some practical aspects. Antioxidants (Basel). 2020; 9 (9): 852. DOI: 10.3390/ antiox9090852. PubMed PMID: 32927924.

3. Khavinson VKh. Peptide medicines: past, present, future. Klinicheskaia meditsina. 2020; 98(3): 165-77. DOI: https://doi. org/10.30629/0023-2149-2020-98-3-165-177. Russian.

4. Perlikowska R. Whether short peptides are good candidates for future neuroprotective therapeutics? Peptides. 2021 140: 170528. DOI: 10.1016/j.peptides.2021.170528. PMID: 33716091.

5. Koroleva SV, Myasoedov NF. Semax as a universal drug for therapy and research. Biol Bull. 2018; (45): 589-600. DOl:10.1134/ S1062359018060055

6. Bobyntsev II, Kryukov AA, Shepeleva OM, Ivanov AV. The effect of ACTH-4-7-PGP peptide on lipid peroxidationin liver and activity of serum transaminases in rats under acute and chronic immobilization stress conditions. Eksperimentalnaya i Klinicheskaya Farmakologiya. 2015; 78 (8): 18-21. DOI: https:// doi.org/10.30906/0869-2092-2015-78-8-18-21. Russian.

7. Dmitriyeva VG, Dergunova LV, Povarova OV, Skvortsova VI, Limborskaya SA, Myasoyedov NF. Deystviye semaksa i ego S-kontsevogo tripeptida PGP na ekspressiyu genov faktorov rosta i ikh retseptorov $v$ usloviyakh eksperimental'noy ishemii mozga krys. Doklady Akademii Nauk. 2008; 422 (2): 258-61. Russian.

8. Levitskaya NG, Kamensky AA. Melanocortin system. Progress in physiological science. 2009; 40 (1): 44-65. Russian.

9. Dodonova SA, Bobyntsev II, Belykh AE, Vorvul AO. ACTH6-9PGP improves memory consolidation processes in rats. Research Results in Pharmacology. 2021; 7 (1): 27-32. DOI: 10.3897/ rrpharmacology.7.62479.

10. Zheng J, Dobner A, Babygirija R, Ludwig K, Takahashi T. Effects of repeated restraint stress on gastric motility in rats. Am J Physiol Regul Integr Comp Physiol. 2009; 296 (5): R1358-65. DOl: 10.1152/ajpregu.90928.2008.

11. Mukhina AY, Mishina ES, Bobyntsev II, Medvedeva OA, Svishcheva MV, Kalutskii PV, et al. Morphological changes in the large intestine of rats subjected to chronic restraint stress and treated with Selank. Bull Exp Biol Med. 2020; 169 (2): 281-5. DOl: https://doi.org/: 10.1007/s10517-020-04868-9. PubMed PMID: 32651826 .

12. R Core Team. R: A language and environment for statistical computing. R Foundation for Statistical Computing, Vienna Austria. 2020. Available from: https://www.R-project.org/.

13. Liu Z, Cai Y, He J. High serum levels of $8-\mathrm{OHdG}$ are an independent predictor of post-stroke depression in Chinese stroke survivors. Neuropsychiatr Dis Treat. 2018; 14: 587-96. DOI: 10.2147/NDT. S155144. PubMed PMID: 29497302.

14. Katerji M, Filippova M, Duerksen-Hughes P. Approaches and methods to measure oxidative stress in clinical samples: research applications in the cancer field. Oxid Med Cell Longev. 2019; 2019: 1279250. DOI: 10.1155/2019/1279250. PubMed PMID: 30992736

15. Ighodaro OM, Akinloye OA. First line defence antioxidantssuperoxide dismutase (SOD), catalase (CAT) and glutathione peroxidase (GPX): Their fundamental role in the entire antioxidant defence grid. Alexandria Journal of Medicine. 2018; 54 (4): 28793. DOI: https://doi.org/10.1016/j.ajme.2017.09.001

16. Ściskalska M, Ołdakowska M, Marek G, Milnerowicz H. Changes in the Activity and concentration of superoxide dismutase isoenzymes (Cu/Zn SOD, MnSOD) in the blood of healthy subjects and patients with acute pancreatitis. Antioxidants (Basel). 2020; 9 (10): 948. DOI: 10.3390/antiox9100948. PubMed PMID: 33019780.

17. Yisireyili M, Alimujiang A, Aili A, Li Y, Yisireyili S, Abudureyimu K. Chronic restraint stress induces gastric mucosal inflammation with enhanced oxidative stress in a murine model. Psychol Res Behav Manag. 2020; 13: 383-93. DOI: 10.2147/PRBM.S250945. PubMed PMID: 32440237.

18. Ranjbar H, Radahmadi M, Reisi P, Alaei H. Effects of electrical lesion of basolateral amygdala nucleus on rat anxiety-like behaviour under acute, sub-chronic, and chronic stresses. Clin Exp Pharmacol Physiol. 2017; 44 (4): 470-9. DOI: 10.1111/14401681.12727. PubMed PMID: 28063155

19. Gokul M, Arun Kumar N, Durgadas Kini R, et al. Evaluation of biomarkers of stress in chronic stress-exposed comorbid depression model Wistar rats. J Basic Clin Physiol Pharmacol. 2019; 30 (5). DOI: 10.1515/jbcpp-2018-0215. PubMed PMID: 31469653.

20. Ghalwash M, Elmasry A, Omar NMA. Possible cardioprotective role of NaHS on ECG and oxidative stress markers in an unpredictable chronic mild stress model in rats. Can J Physiol Pharmacol. 2021; 99 (3): 321-7. DOI: 10.1139/cjpp-2019-0646. PubMed PMID: 33175584.

21. Gorodetskaya IV, Korenevskaya NA Thyroid hormones influence on lipid peroxidation changes due to the acute and chronic stress. Izvestiya Natsional'noy akademii nauk Belarusi. Seriya meditsinskikh nauk. 2010; 1: 78-84. Russian.

22. Stavchansky VV, Tvorogova TV, Botsina AY, Skvortsova VI, Limborska SA, Mysoedov NF, Dergunova LV. Effect of semax and its C-terminal peptide PGP on expression of neurotrophins and their receptors in rat brain during incomplete global ischemia. Mol Biol. 2011; 45 (6): 941-9. DOI: https://doi.org/10.1134/ S0026893311050128.

23. Kulaga EA, Gavrilova SA, Buravkov SV, Koshelev VB. Dynamics of the brain-derived neurotrophic factor (BDNF) expression in the rats cerebral cortex and the effect of the drug "Semax" for BDNF production after ischemic stroke. Regional blood circulation and microcirculation. 2013; 12 (3): 39-46. DOI: https://doi. org/10.24884/1682-6655-2013-12-3-39-46. Russian.

24. Chugunov AV, Kamchatnov PV, Mikhailova NA. Correction of freeradical oxidation as a pathogenetic approach to the treatment of acute ischemic stroke. Zhurnal nevrologii i psikhiatrii. 2009; 10 (2): 65-8. Russian.

25. Levichkin VD, Remenyakina El, Pavlyuchenko II, Kade AKh, Trofimenko Al, Zanin SA. Influence of TES-therapy on indicators of system of pro/antioksidanty at rats with the experimental ischemic stroke. Sovremennyye problemy nauki i obrazovaniya. 2014; (2): 332. Russian.

26. Akimov MG, Fomina-Ageeva EV, Dudina PV, Andreeva LA, Myasoyedov NF, Bezuglov W. ACTH(6-9)PGP peptide protects $\mathrm{SH}-\mathrm{SY} 5 Y$ cells from $\mathrm{H} 2 \mathrm{O} 2$, tert-butyl hydroperoxide, and cyanide cytotoxicity via stimulation of proliferation and induction of prosurvival-related genes. Molecules. 2021; 26 (7): 1878. DOI: 10.3390/molecules26071878. PubMed PMID: 33810344.

27. Black CN, Bot $M$, Révész $D$, Scheffer PG, Penninx B. The association between three major physiological stress systems and oxidative DNA and lipid damage. Psychoneuroendocrinology. 2017; 80: 56-66. DOI: 10.1016/j.psyneuen.2017.03.003.

28. Clark AJ, Forfar R, Hussain M, Jerman J, Mclver E, Taylor D, Chan L. ACTH antagonists. Front Endocrinol (Lausanne). 2016; (7): 101. DOI: 10.3389/fendo.2016.00101. PubMed PMID: 27547198.

29. Konda Y, Gantz I, DelValle J, Shimoto Y, Miwa H, Yamada T. Interaction of dual intracellular signaling pathways activated by the 
melanocortin-3 receptor. J Biol Chem. 1994; 269 (18): 13162-6. PubMed PMID: 8175743.

30. Buggy JJ. Binding of alpha-melanocyte-stimulating hormone to its G-protein-coupled receptor on B-lymphocytes activates the Jak/STAT pathway. Biochem J. 1998; 331 (Pt 1) (Pt 1): 211-6. DOI: 10.1042/bj3310211. PubMed PMID: 9512481.

\section{Литература}

1. Sies $H$, Berndt $\mathrm{C}$, Jones DP. Oxidative stress. Annu Rev Biochem. 2017; 86: 715-48. DOI: 10.1146/annurevbiochem-061516-045037. PubMed PMID: 28441057.

2. Sies H. Oxidative stress: concept and some practical aspects. Antioxidants (Basel). 2020; 9 (9): 852. DOI: 10.3390/ antiox9090852. PubMed PMID: 32927924.

3. Хавинсон В. Х. Лекарственные пептидные препараты: прошлое, настоящее, будущее. Клиническая медицина. 2020; 98 (3): 16577. DOl: https://doi.org/10.30629/0023-2149-2020-98-3-165-177.

4. Perlikowska R. Whether short peptides are good candidates for future neuroprotective therapeutics? Peptides. 2021; 140: 170528. DOI: 10.1016/i.peptides.2021.170528. PMID: 33716091.

5. Koroleva SV, Myasoedov NF. Semax as a universal drug for therapy and research. Biol Bull. 2018; (45): 589-600. DOI:10.1134/ S1062359018060055.

6. Бобынцев И. И., Крюков А. А., Шепелева О. М., Иванов А. В. Влияние пептида АКТГ4-7-ПГП на перекисное окисление липидов в печени крыс и активность сывороточных трансаминаз в условиях иммобилизационного стресса. Экспериментальная и клиническая фармакология. 2015; 78 (8): 18-21. DOI: https://doi. org/10.30906/0869-2092-2015-78-8-18-21.

7. Дмитриева В. Г., Дергунова Л. В., Поварова О. В., Скворцова В. И., Лимборская С. А., Мясоедов Н. Ф. Действие семакса и его С-концевого трипептида PGP на экспрессию генов факторов роста и их рецепторов в условиях экспериментальной ишемии мозга крыс. Доклады Академии Наук. 2008; 422 (2): 258-61.

8. Левицкая Н. Г., Каменский А. А. Меланокортиновая система. Успехи физиологических наук. 2009; 40 (1): 44-65.

9. Dodonova SA, Bobyntsev II, Belykh AE, Vorvul AO. ACTH6-9PGP improves memory consolidation processes in rats. Research Results in Pharmacology. 2021; 7 (1): 27-32. DOI: 10.3897/ rrpharmacology.7.62479.

10. Zheng J, Dobner A, Babygirija R, Ludwig K, Takahashi T. Effects of repeated restraint stress on gastric motility in rats. Am J Physiol Regul Integr Comp Physiol. 2009; 296 (5): R1358-65. DOI: 10.1152/ajpregu.90928.2008.

11. Mukhina AY, Mishina ES, Bobyntsev II, Medvedeva OA, Svishcheva MV, Kalutskii PV, et al. Morphological changes in the large intestine of rats subjected to chronic restraint stress and treated with Selank. Bull Exp Biol Med. 2020; 169 (2): 281-5. DOI: https://doi.org/: 10.1007/s10517-020-04868-9. PubMed PMID: 32651826.

12. R Core Team. R: A language and environment for statistical computing. R Foundation for Statistical Computing, Vienna, Austria. 2020. Available from: https://www.R-project.org/.

13. Liu Z, Cai Y, He J. High serum levels of $8-O H d G$ are an independent predictor of post-stroke depression in Chinese stroke survivors. Neuropsychiatr Dis Treat. 2018; 14: 587-96. DOI: 10.2147/NDT S155144. PubMed PMID: 29497302.

14. Katerii M, Filippova M, Duerksen-Hughes P. Approaches and methods to measure oxidative stress in clinical samples: research applications in the cancer field. Oxid Med Cell Longev. 2019; 2019: 1279250. DOI: 10.1155/2019/1279250. PubMed PMID: 30992736.

15. Ighodaro OM, Akinloye OA. First line defence antioxidantssuperoxide dismutase (SOD), catalase (CAT) and glutathione peroxidase (GPX): Their fundamental role in the entire antioxidant defence grid. Alexandria Journal of Medicine. 2018; 54 (4): 28793. DOI: https://doi.org/10.1016/j.ajme.2017.09.001.

16. Ściskalska M, Ołdakowska M, Marek G, Milnerowicz H. Changes in the Activity and concentration of superoxide dismutase isoenzymes (Cu/Zn SOD, MnSOD) in the blood of healthy subjects and patients with acute pancreatitis. Antioxidants (Basel). 2020; 9 (10): 948. DOl: 10.3390/antiox9100948. PubMed PMID: 33019780.

17. Yisireyili M, Alimujiang A, Aili A, Li Y, Yisireyili S, Abudureyimu K. Chronic restraint stress induces gastric mucosal inflammation with enhanced oxidative stress in a murine model. Psychol Res Behav Manag. 2020; 13: 383-93. DOI: 10.2147/PRBM.S250945. PubMed PMID: 32440237.

18. Ranjbar H, Radahmadi M, Reisi P, Alaei H. Effects of electrical lesion of basolateral amygdala nucleus on rat anxiety-like behaviour under acute, sub-chronic, and chronic stresses. Clin Exp Pharmacol Physiol. 2017; 44 (4): 470-9. DOI: 10.1111/14401681.12727. PubMed PMID: 28063155.

19. Gokul M, Arun Kumar N, Durgadas Kini R, et al. Evaluation of biomarkers of stress in chronic stress-exposed comorbid depression model Wistar rats. J Basic Clin Physiol Pharmacol. 2019; 30 (5). DOI: 10.1515/ibcpp-2018-0215. PubMed PMID: 31469653.

20. Ghalwash M, Elmasry A, Omar NMA. Possible cardioprotective role of NaHS on ECG and oxidative stress markers in an unpredictable chronic mild stress model in rats. Can J Physiol Pharmacol. 2021; 99 (3): 321-7. DOI: 10.1139/cjpp-2019-0646. PubMed PMID: 33175584.

21. Городецкая И. В., Кореневская Н. А. Влияние тиреоидных гормонов на изменения перекисного окисления липидов, вызванные острым и хроническим стрессом. Известия Национальной академии наук Беларуси. Серия медицинских наук. 2010; 1: 78-84.

22. Stavchansky VV, Tvorogova TV, Botsina AY, Skvortsova VI, Limborska SA, Mysoedov NF, Dergunova LV. Effect of semax and its C-terminal peptide PGP on expression of neurotrophins and their receptors in rat brain during incomplete global ischemia. Mol Biol. 2011; 45 (6): 941-9. DOI: https://doi.org/10.1134/ S0026893311050128.

23. Кулага Е. А., Гаврилова С. А., Буравков С. В., Кошелев В. Б. Динамика экспрессии мозгового нейротрофического фактора (BDNF) в коре головного мозга крыс и влияние препарата «Семакс» на его продукцию при моделировании ишемического инсульта. Регионарное кровообращение и микроциркуляция. 2013; 12 (3): 39-46. DOI: https://doi. org/10.24884/1682-6655-2013-12-3-39-46.

24. Чугунов А. В., Камчатнов П. В., Михайлова Н. А. Коррекция свободнорадикального окисления - патогенетический подход к лечению острого ишемического инсульта. Журнал неврологии и психиатрии. 2009; 10 (2): 65-8.

25. Левичкин В. Д., Ременякина Е. И., Павлюченко И. И., Каде А. Х., Трофименко А. И., Занин С. А. Влияние ТЭС-терапии на показатели системы про/антиоксиданты у крыс с экспериментальным ишемическим инсультом. Современные проблемы науки и образования. 2014; (2): 332.

26. Akimov MG, Fomina-Ageeva EV, Dudina PV, Andreeva LA, Myasoyedov NF, Bezuglov W. ACTH(6-9)PGP peptide protects $\mathrm{SH}-\mathrm{SY} 5 \mathrm{Y}$ cells from $\mathrm{H} 2 \mathrm{O} 2$, tert-butyl hydroperoxide, and cyanide cytotoxicity via stimulation of proliferation and induction of prosurvival-related genes. Molecules. 2021; 26 (7): 1878. DOI: 10.3390/molecules26071878. PubMed PMID: 33810344.

27. Black CN, Bot M, Révész D, Scheffer PG, Penninx B. The association between three major physiological stress systems and oxidative DNA and lipid damage. Psychoneuroendocrinology. 2017; 80: 56-66. DOI: 10.1016/j.psyneuen.2017.03.003.

28. Clark AJ, Forfar R, Hussain M, Jerman J, Mclver E, Taylor D, Chan L. ACTH antagonists. Front Endocrinol (Lausanne). 2016; (7): 101. DOI: 10.3389/fendo.2016.00101. PubMed PMID: 27547198.

29. Konda Y, Gantz I, DelValle J, Shimoto Y, Miwa H, Yamada T. Interaction of dual intracellular signaling pathways activated by the melanocortin-3 receptor. J Biol Chem. 1994; 269 (18): 13162-6. PubMed PMID: 8175743.

30. Buggy JJ. Binding of alpha-melanocyte-stimulating hormone to its G-protein-coupled receptor on B-lymphocytes activates the Jak/STAT pathway. Biochem J. 1998; 331 (Pt 1) (Pt 1): 211-6. DOI: 10.1042/bj3310211. PubMed PMID: 9512481. 